The Bangladesh Veterinarian (2011) 28(2) : 60 - 69

\title{
Pathological study on the upper respiratory tract infection of chickens and isolation, identification of causal bacteria
}

\author{
N. Popy, M. Asaduzzaman, M. S. Miah, A. Siddika, M. A. Sufian and \\ M. M. Hossain* \\ Department of Pathology, Faculty of Veterinary Science, Bangladesh Agricultural \\ University, Mymensingh-2202, Bangladesh
}

\begin{abstract}
The proportional occurrence of bacteria and pathological lesions in the nasal sinuses and trachea of dead chickens were determined during 2008-2009. Nasal sinus and tracheal swabs from 50 dead birds were collected in sterile nutrient broth. The histopathological samples were collected in 10\% neutral buffered formalin and studied with light microscope. The isolation and identification of bacteria were performed by culture, staining and biochemical tests. The proportional occurrence of bacteria in trachea $(n=50)$ and nasal sinuses $(\mathrm{n}=50)$ of dead chickens was Klebsiella sp. $(6.0 \%)$, Escherichia coli $(38.8 \%)$, Pasteurella sp. (8.6\%), Bacillus sp. (5.2\%) and Staphylococcus sp. (41.4\%). Congested trachea $(n=3)$ and mucus-filled sinuses $(n=3)$ of dead chickens were studied for histopathology. Microscopically, rhinitis was characterized by infiltration of macrophages, lymphocytes and few neutrophils. The epithelium of nasal passage revealed pyknotic nucleus with disruption of epithelium. There was sinusitis with purulent and necrotic changes around the nasal sinus. The nasal sinuses were infiltrated with macrophages, lymphocytes and few plasma cells. The mucosal layer of the nasal turbinates showed pus and necrosis. There was disruption of different mucous glands with accumulation of macrophages, lymphocytes and plasma cells in the submucosa. (Bangl. vet. 2011. Vol. 28, No. 2, 60 - 69)
\end{abstract}

\section{Introduction}

In birds, several bacteria, Pasteurella multocida, Pasteurella gallinarum, Mannheimia haemolytica and Pasteurella anatipestifer, Bordetella avium and Haemophilus paragallinarum are involved in respiratory disease (Hafez, 2002). Escherichia coli are also associated with respiratory infection in chickens (Sukhon et al., 2002). Ornithobacterium rhinotracheale has recently been identified as causing respiratory tract infections in poultry and other birds (Vandamme et al., 1994; Chin et al., 2003). Concurrent infection of young poultry with Klebsiella pneumoniae increased the severity of respiratory disease (Saif, 2003). Weakness, gasping, pump-handled respiration, dyspnoea, mucous discharge and mortality, swelling of sinuses, facial oedema, tracheitis, exudative pneumonia, pleuritis, air sacculitis, pericarditis, sinusitis, drop in egg production and poor egg quality characterize the respiratory infection (Zorman et al., 2000; Canal et al., 2005).

\footnotetext{
*Corresponding author:- E-mail: mmhossain04@yahoo.com.au
} 
Confirmatory diagnosis of bacterial diseases of upper respiratory tract infection in poultry requires more data. The investigation was designed to (a) isolate and identify the bacteria from nasal sinuses and trachea and to (b) determine the pathological lesions caused by these bacteria.

\section{Materials and Methods}

Samples

A total of 100 swabs were collected for bacteriological isolation in nutrient broth from July 2008 to June 2009, of which 25 tracheal and 25 nasal sinus swabs came from KFL, Trishal, Mymensingh, 15 tracheal and 15 nasal sinus swabs from SK Veterinary Diagnostic Centre (SKVDC), Durgabari Road, Mymensingh, and 10 tracheal and 10 nasal sinus swabs from necropsy cases. Gross lesions such as congested trachea and mucus-filled sinuses of one dead bird from KFL, Trishal, Mymensingh, one from SKVDC, Durgabari Road, Mymensingh, and one from the Department of Pathology were collected for histopathology in $10 \%$ buffered formalin.

Primary culture of organisms

From the nutrient broth 50 tracheal and 50 nasal sinus swabs were placed in nutrient agar plate and incubated overnight at $37^{\circ} \mathrm{C}$.

\section{Subculture}

All swab samples (50 tracheal and 50 nasal sinuses) were subcultured in nutrient agar, MacConkey agar and Eosin Methylene Blue (EMB) agar. Blood agar was used only for Pasteurella and Bacillus spp. A small amount of inoculum from the nutrient agar was spread into culture media and incubated at $37^{\circ} \mathrm{C}$ overnight. The organisms were identified by colony morphology, staining character and biochemical tests (Merchant and Packer, 1967; Curtis, 1985; Cheesbrough, 1985; Buxton and Fraser, 1977; Ali et al., 1998; Granum, 2001; Brooks et al., 2002; Naowarat, 2007).

\section{Histopathology}

Three tracheal and three nasal sinus tissues from three dead birds were selected for histopathology. The formalin-fixed tissues were processed following standard procedures (Luna, 1968).

\section{Photomicrography}

Photomicrographs were taken using Olympus PM-C 35 camera fitted with Olympus microscope (Olympus, Japan).

\section{Results and Discussion}

The clinical signs observed were depression, conjunctivitis, frothy oculo-nasal discharge, conjunctivitis, facial oedema, and respiratory rales. Gross pathology results are illustrated in Figs. 1-6. 

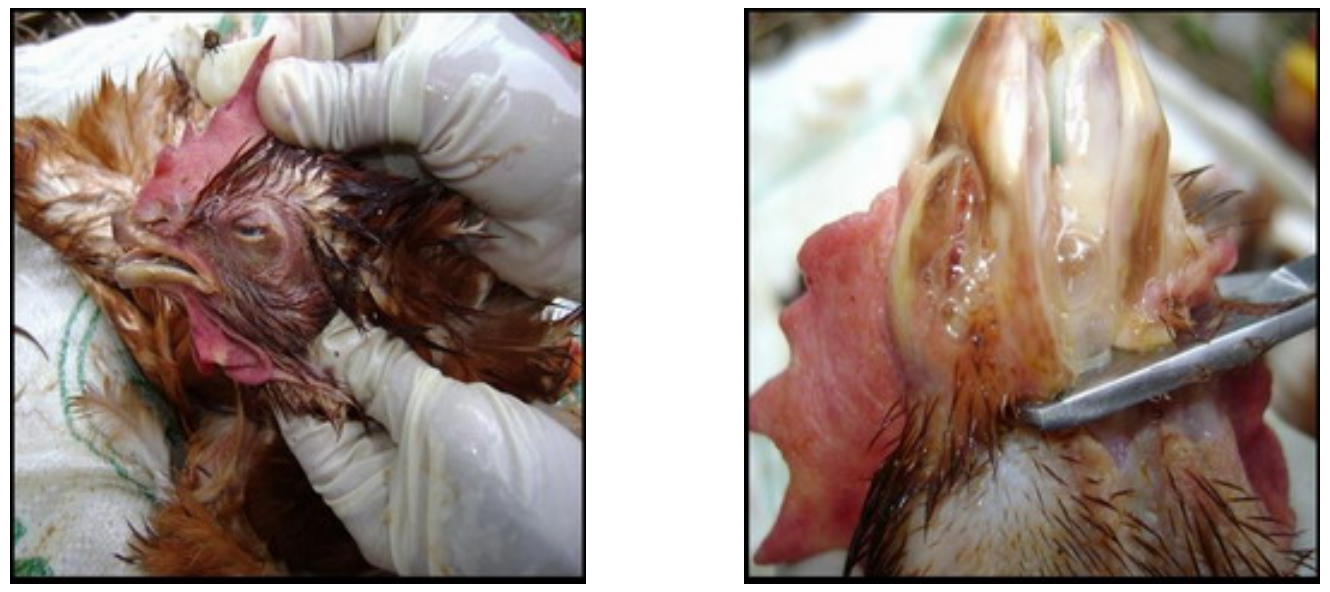

Figs. 1 and 2. Frothy oculo-nasal discharge in chicken infected with E. coli
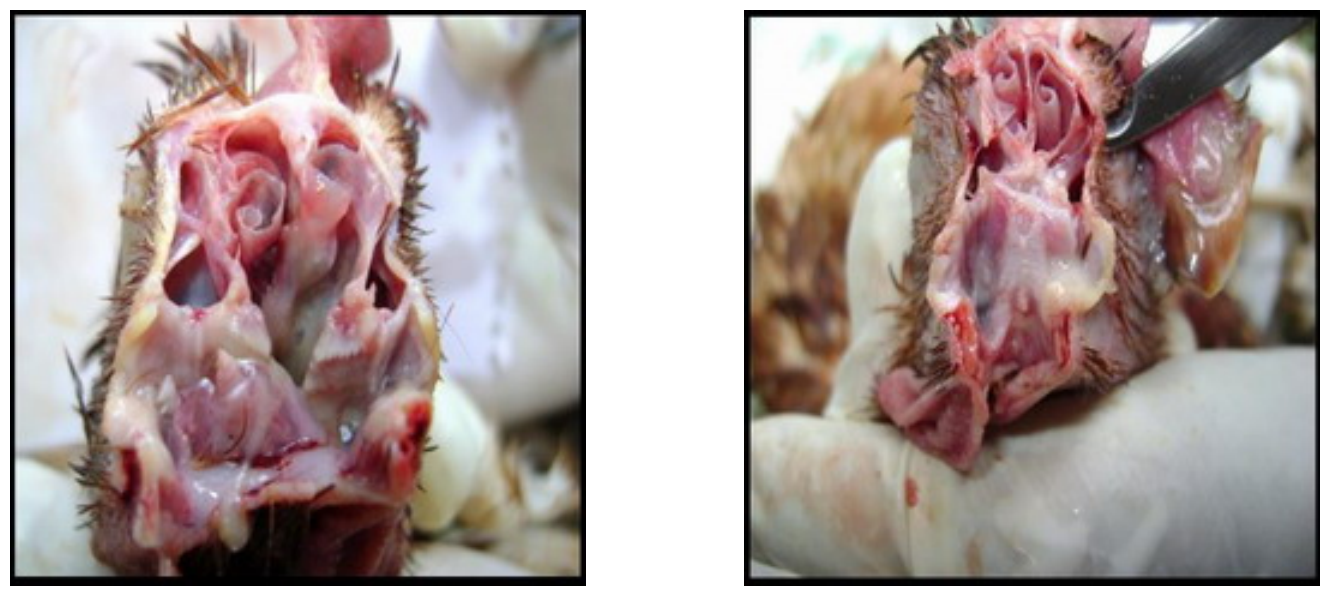

Figs. 3 and 4. Mucoid exudate in the nasal sinus in chickens infected with E. coli
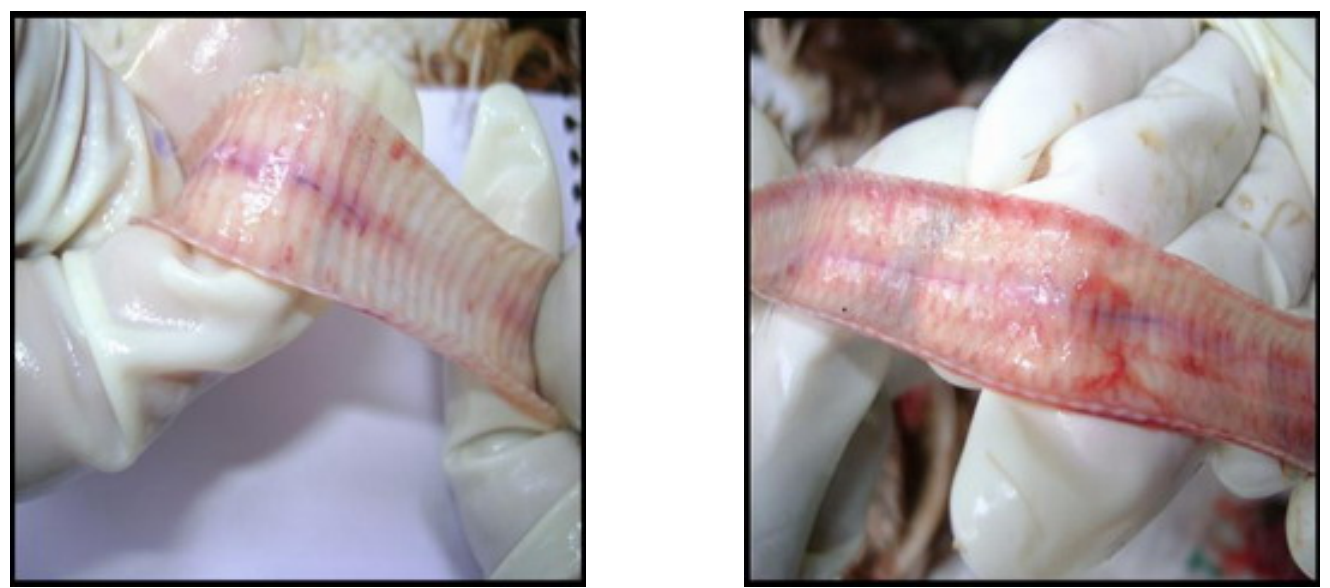

Figs. 5 and 6. Congested trachea in E. coli infected chickens 
From subculture of 100 swabs from nasal sinus and trachea, 116 isolates were found. The isolates were Klebsiella sp. $(\mathrm{n}=7)$, E. coli $(\mathrm{n}=45)$, Pasteurella sp. $(\mathrm{n}=10)$, Bacillus sp. $(\mathrm{n}=6)$ and Staphylococcus sp. $(\mathrm{n}=48)$. Three isolates of each group were subjected to confirmation by culture, staining characters and by biochemical tests (Figs. 7-16).

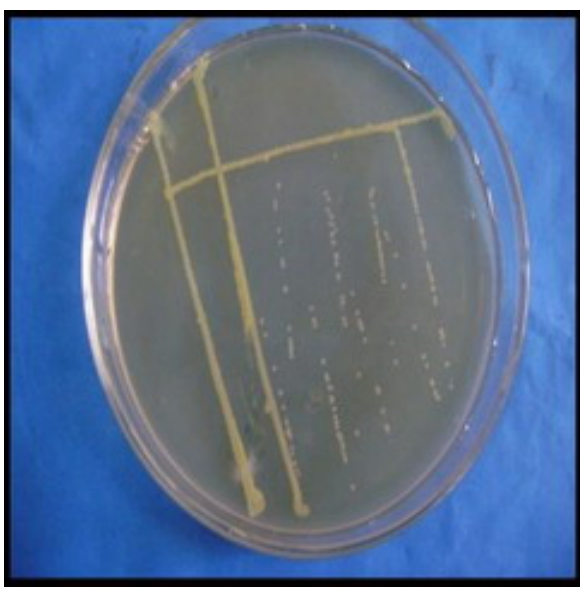

Fig. 7. Culture of Staphylococcus on nutrient agar showing yellow colored colonies

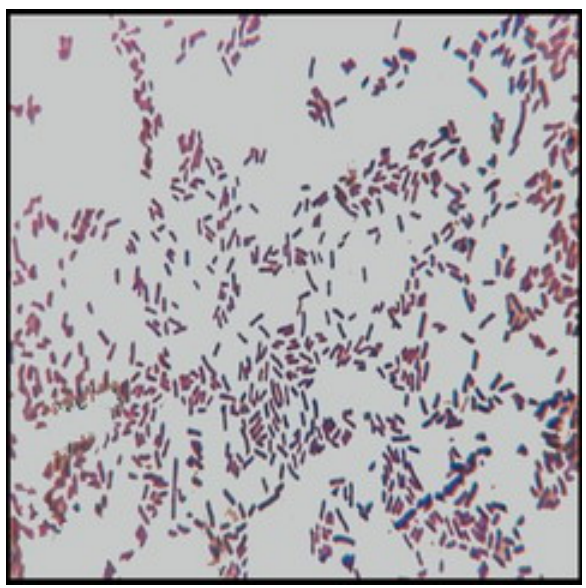

Fig. 9. E. coli in Gram's staining showing gram negative, short rod shaped organisms, arranged in single and paired (Gram's stain, $\times 830$ )

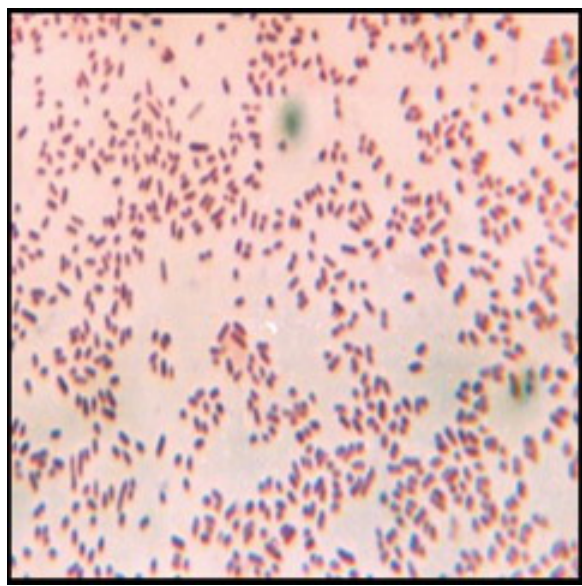

Fig. 8. Klebsiella sp. shows gram negative, coccobacillary shaped organism. (Modified Gram's staining, ×830)

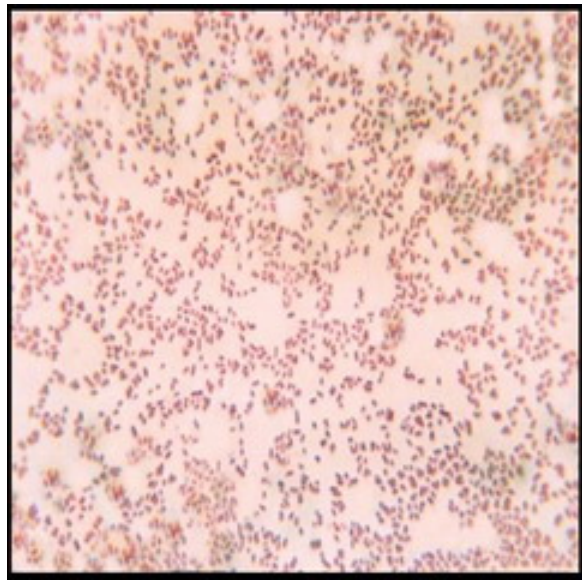

Fig. 10. Pasturella sp. showing gram negative and coccobacillary shaped organism with bipolar appearance (Leishman's stain, $\times 830$ )

The bacteria found in trachea (50 swabs) with the proportion of each as a percentage of all bacteria found, in parentheses, were Klebsiella sp. (6.6\%), Escherichia coli $(37.7 \%)$, Pasteurella sp. (11.5\%), Bacillus sp. (3.3\%), Staphylococcus sp. (41.0\%) (Table 1). In nasal sinuses (50 swabs) the proportion was Klebsiella sp. (5.5\%), Escherichia coli (40\%), Pasteurella sp. (5.5\%), Bacillus sp. (7.3\%), Staphylococcus sp. (41.8\%); (Table 2). 
Table 1. Bacteria isolated from trachea of dead chickens $(n=50)$

\begin{tabular}{c|l|c|c}
\hline Serial No. & \multicolumn{1}{|c|}{ Organisms } & Number of isolated bacteria & \% of isolated bacteria \\
\hline 1 & Klebsiella sp. & 4 & 6.6 \\
2 & Escherichia coli & 23 & 37.7 \\
3 & Pasteurella $s p$. & 7 & 11.5 \\
4 & Bacillus sp. & 2 & 3.3 \\
5 & Staphylococcus sp. & 25 & 41.0 \\
\hline
\end{tabular}

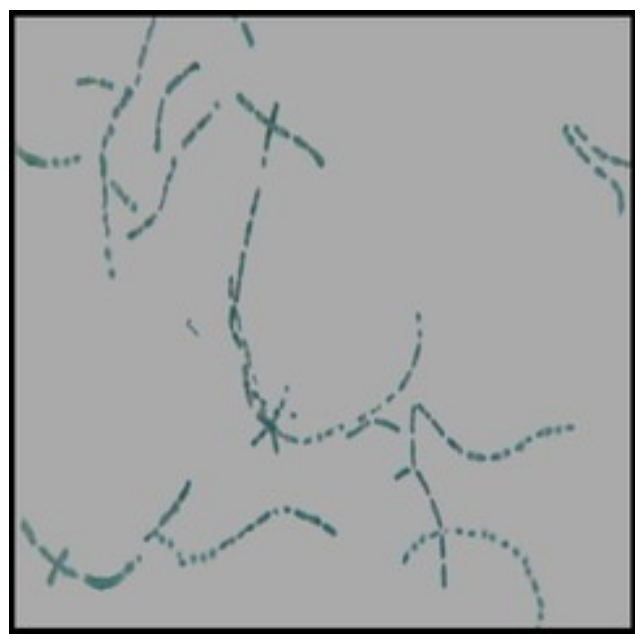

Fig. 11. Bacillus sp. showing gram positive, cylindrical rod arranged in single and long chain. (Modified Gram's staining, $\times 830$ )

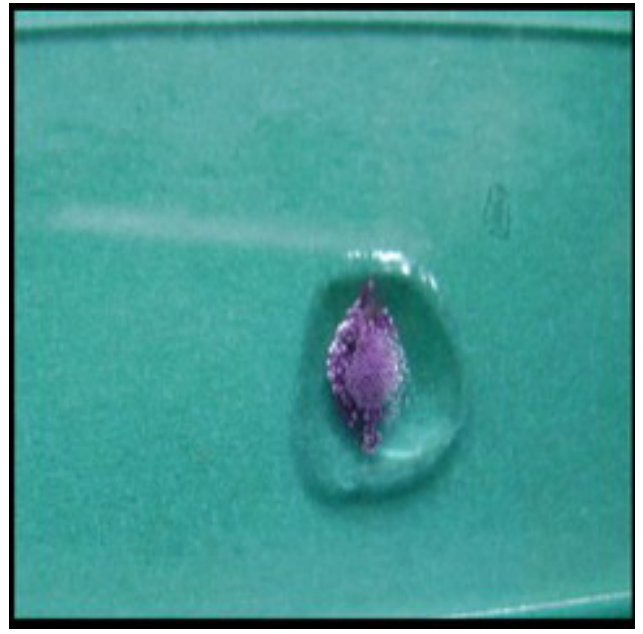

Fig. 13. Catalase positive (gas bubble) for E. coli

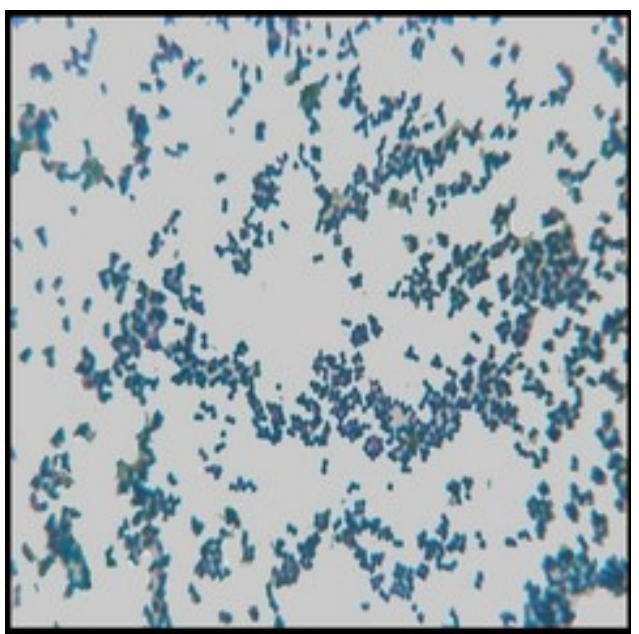

Fig. 12. Staphylococcus sp. showing gram positive, cocci and arranged in grape like clusters (Modified Gram's staining, $\times 830$ )

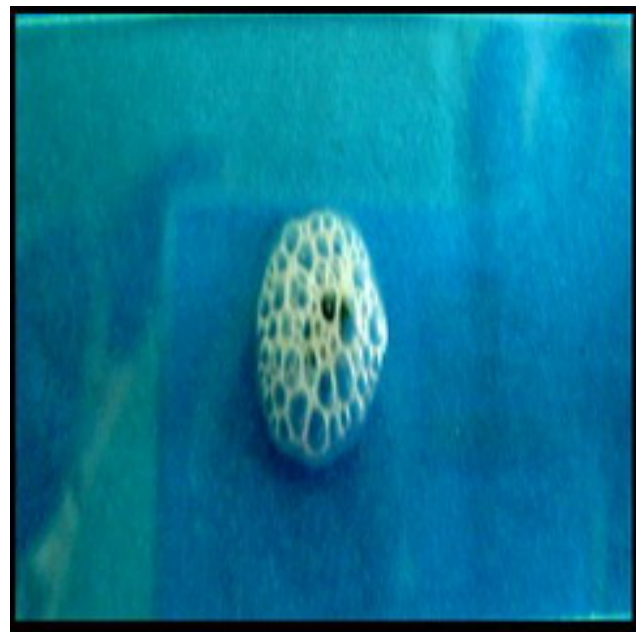

Fig. 14. Catalase positive (gas bubble) for Pasturella sp. 
Table 2. Bacteria isolated from nasal sinuses of dead chickens $(n=50)$

\begin{tabular}{c|l|c|c}
\hline Serial No. & \multicolumn{1}{|c|}{ Organisms } & Number of isolated bacteria & \% of isolated bacteria \\
\hline 1 & Klebsiella $s p$. & 3 & 5.5 \\
2 & Escherichia coli & 22 & 40.0 \\
3 & Pasteurella $s p$. & 3 & 5.5 \\
4 & Bacillus $s p$. & 4 & 7.3 \\
5 & Staphylococcus sp. & 23 & 41.8 \\
\hline
\end{tabular}

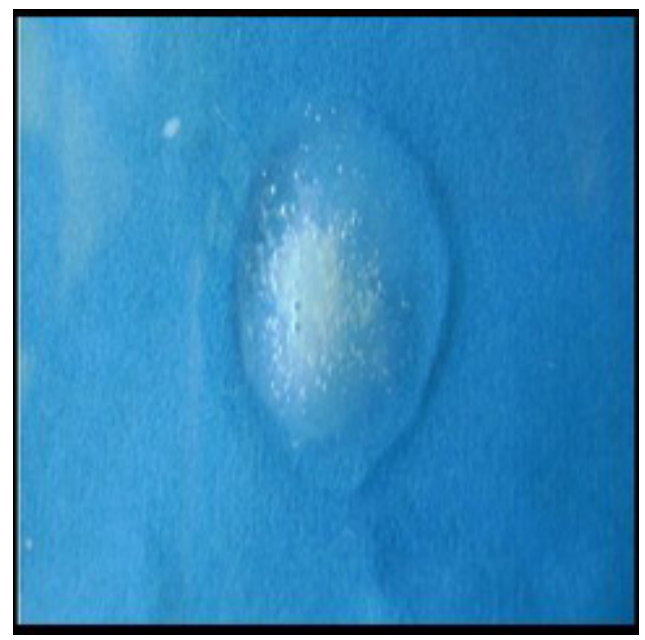

Fig. 15. Catalase positive (gas bubble) for Bacillus sp.

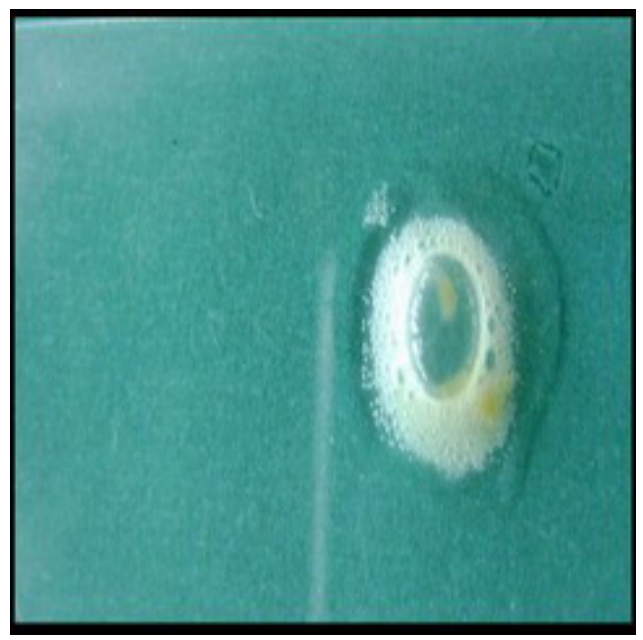

Fig. 16. Catalase positive (gas bubble) for Staphylococcus sp.

The proportion of bacteria in trachea and sinuses together was 6\% Klebsiella sp., 38.8\% Escherichia coli, 8.6\% Pasteurella sp., 5.2\% Bacillus sp., and 41.4\% Staphylococcus sp. (Table 3, Figs. 7-16).

The overall proportion of Klebsiella sp. (6\%) was lower than from other authors (Ibrahim et al., 2004; Trkyilmaz, 2005). This might be due to age and breeds of the chickens, geographic variation and management, vaccination and nutrition.

The proportion of E. coli in tracheal and nasal sinus swabs (38.8\%) was lower than those reported by some (Georgiades et al., 2001; Murakami et al., 2002; Yousseff et al., 2008) but higher than the findings of others (Ibrahim et al., 2004; Trkyilmaz, 2005). This might be due to age and breeds of the chickens and management. The proportion of Pasteurella sp. from trachea and sinuses was 8.6\%, lower than other reports (Murakami et al., 2002; Trkyilmaz, 2005). The proportion of Bacillus sp. in trachea and nasal sinuses, 5.2\%, was lower than Trkyilmaz (2005). Staphylococcus sp. formed $41.4 \%$ of the bacteria found in the trachea and nasal sinuses of dead chickens, lower than found by Trkyilmaz (2005). 
The bacteria isolated from the nasal sinuses were E. coli, Pasteurella sp., Klebsiella sp. Bacillus sp. and Staphylococcus. E. coli are thought to cause disease in poultry including respiratory infection such as swollen head syndrome and respiratory colibacillosis; Pasteurella $s p$. is the cause of fowl cholera and induces pneumonia, chronic rhinitis, facial oedema; Klebsiella sp., E. coli and Pasteurella sp. together cause pneumonia and tracheitis (Drago and Don, 1996; Fouad and Mohamed, 2008; Moursi and Sabah, 2008). According to the lesions of nasal sinuses, the disease in this study may be sinusitis.

In field cases of respiratory tract diseases in chickens, it is important to recognize that mixed infection with other organisms aggravate the clinical disease. These other micro-organisms include Mycoplasma sp. H. paragallinarum and many viruses. In this present study Mycoplasma sp. and H. paragallinarum infection were not studied.

\section{Histopathological study}

Gross lesions such as congested trachea and mucus-filled sinuses were studied for histopathology (Table 3). Microscopically, the section of the nose showed rhinitis characterized by excessive infiltration of macrophages, lymphocytes and a few neutrophils. The epithelium of nasal passage revealed pyknotic nucleus with disruption of epithelium. There was sinusitis with purulent and necrotic changes around the sinus with the infiltration of macrophages, lymphocytes and plasma cells. There was disruption of different mucous gland with accumulation of macrophages, lymphocytes and plasma cells in the submucosa (Figs. 17 and 18). The mucosal layer of the nasal turbinates showed pus and necrosis. There was no lesion in the trachea. Similar lesions were reported by many investigators (Nakamura et al., 1997; Rocio et al., 1998; Murakami et al., 2002; Jaswinder et al., 2005).

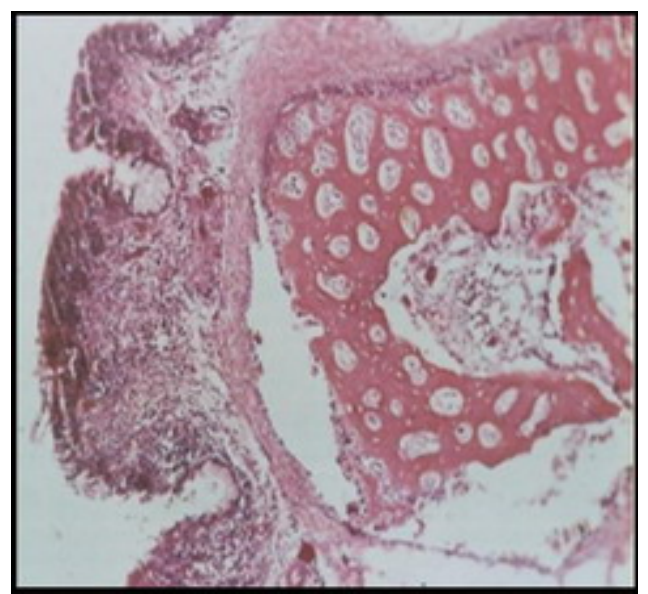

Fig. 17. Section of nose showing rhinitis with disruption of epithelial layer, presence of pyknotic nuclei and infiltration of macrophages, lymphocytes and few plasma cells $(\mathrm{H} \& \mathrm{E}$ stain, $\times 83$ )

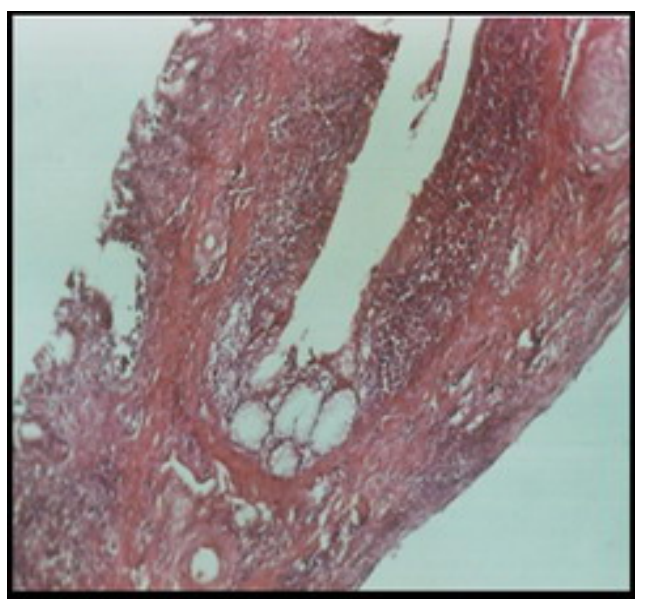

Fig. 18. Section of nose showing focal purulent and necrotic changes of the mucosal membrane in the nasal turbinate (H\&E stain, $\times 333$ ) 
Table 3. Bacteria identified from trachea and nasal sinuses of dead chickens

\begin{tabular}{c|l|c|c}
\hline Serial no. & Isolated organisms & Number of isolated bacteria & \% of isolated bacteria \\
\hline 1 & Klebsiella sp. & 116 & 6.0 \\
2 & Escherichia coli & & 38.8 \\
3 & Pasteurella sp. & 8.6 \\
4 & Bacillus sp. & 5.2 \\
5 & Staphylococcus sp. & 41.4 \\
\hline
\end{tabular}

\section{Conclusions}

In this study, Klebsiella sp. (6.0\%), Escherichia coli (38.8\%), Pasteurella sp. (8.6\%), Bacillus sp. (5.2\%) and Staphylococcus sp. (41.4\%) were isolated from trachea and nasal sinuses of chickens. Clinical signs of these affected birds were depression, conjunctivitis, frothy oculo-nasal discharge, conjunctivitis, facial oedema, and respiratory rales. Gross lesions of upper respiratory tracts were catarrhal tracheitis and rhinitis. Microscopic lesions were tracheitis, sinusitis and rhinitis characterized by infiltration of neutrophils, lymphocytes, plasma cells and macrophages at different layers of these tissues.

\section{References}

Ali MY, Rahman MT, Islam MA, Choudhury KA, Rahman MA 1998: Characteristics of E. coli isolates of human and animal origin. Progressive Agriculture 9 221-224.

Brooks GF, Butel JS, Morse SA 2002: Jawetz, Melnick and Adelberg's Medical Microbiology. $22^{\text {nd }}$ edn. MacGraw Hill, New Delhi, India pp. 197-202.

Buxton A, Fraser G 1977: Animal Microbiology. Vol. 1. Blackwell Scientific Publications, Oxford, United Kingdom pp. 103-115.

Canal CW, Leao JA, Rocha SLS, Macagnan M, Lima RCAV, Oliveira SD, Back A 2005: Isolation and characterization of Ornithobacterium rhinotracheale from chickens in Brazil. Research in Veterinary Science 78 225-230.

Carter GR 1979: Diagnostic Procedure in Veterinary Bacteriology and Mycology. $3^{\text {rd }}$ edn. Charles CT, Publishers: Springfield, Illinois, USA pp. 157-161.

Cheesbrough M 1985: Medical Laboratory Manual for Tropical Countries. Vol. 2: Microbiology. ELBS edn. Cambridge, UK pp. 227-232.

Chin RP, Empel VPCM, Hafez HM 2003: Ornithobacterium rhinotracheale infection, In: Disease of Poultry. 11 $1^{\text {th }}$ edn. Saif YM, Barnes HJ, Glisson JR, Fadly A M, McDougald LR, Swayne DE (eds.). Iowa State University Press, Ames, Iowa pp. 683-690.

Choudhury RA, Amin NM, Rahman A, Ali MR 1985: Investigation of natural outbreak of fowl cholera. Bangladesh Veterinary Journal 19 49-56.

Collins CH, Lyne PM 1976: Microbiological Methods. $4^{\text {th }}$ edn. Butterworth and Company Publishers Limited, UK pp. 169-175. 
Curtis PE 1985: Pasteurella multocida. In: Isolation and identification of Microorganisms of Medical and Veterinary Importance. Collins $\mathrm{CH}$, Grange JM (eds.). Academic Press, London, United Kingdom pp. 43-51.

Drago CH, Don AF 1996: Bacterial diseases of respiratory tract. In: Poultry diseases and meat hygiene: a color atlas. $1^{\text {st }}$ edn. Iowa State University Press, Ames, Iowa, USA pp. 283.

Fouad IA, Mohamed HAAE 2008: Bacteriological and pathological studies on Pasteurella haemolytica in ducks in Assiut Governorate. Association of Veterinary Medicine Journal 54 220-230.

Georgiades G, Iordanidis P, Koumbati M 2001: Cases of swollen head syndrome in broiler chickens in Greece. Avian Diseases 45 745-750.

Granum PE 2001: Bacillus cereus. In: Food Microbiology: Fundamentals and Frontiers. $2^{\text {nd }}$ edn. Doyle MP, Beuchat LR, Montville TJ (eds.) pp. 373-381.

Hafez MH 2002: Diagnosis of Ornithobacterium rhinotracheale. International Journal of Poultry Sciences 1 114-118.

Ibrahim RS, Mousa S, Aly M, Naser AWE 2004: Complicated infectious coryza in broiler and layer chickens. Egyptian Association for Veterinary Medical Journal 50103.

Jaswinder K, Banga HS, Sood NK, Kuldip G, Amarjit S 2005: Pathological studies on naturally occurring infectious coryza in chickens. Indian Animal Sciences Journal 75 209-211.

Luis MDM, Marie TP, Janet T, Shigei E, Peterson M 2004: Bacillus subtilis on blood agar In: Color Atlas of Medical Bacteriology. $1^{\text {st }}$ edn. ASM Press American Society for Microbiology, USA pp. 54.

Luna LG 1968: Manual and Histologic Staining Methods of the Armed Forces Institute of Pathology. $3^{\text {rd }}$ edn. McGraw Hill Book Co., New York, USA 85-86.

Merchant IA, Packer RA 1967: Veterinary bacteriology and virology. $7^{\text {th }}$ edn. The Iowa State University Press, Ames, Iowa, USA pp. 211-305.

Moursi MK, Sabah KH 2008: Studies on chickens ornithobacterium sp. infection at Ismailia province. Association for Veterinary Medical Journal 54 357-372.

Murakami SM, Miyama A, Ogawa J, Shimada, Nakane T 2002: Occurrence of conjunctivitis,sinusitis and upper region tracheitis in Japanese quail (Coturnix coturnjaponica), possibly caused by Mycoplasma gallisepticum accompanied by Cryptosporidium sp. infection. Avian Pathology 31 363- 370.

Naowarat C 2007: Eosin-Methylene Blue.Vis. Atl. American Society for Microbiology. http:// www.microbelibrary.org/ASMomly/details.asp?id.

Nakamura K, Mase M, Tanimura N, Yamaguchi S, Nakazawa M, Yuasa N 1997: Swollen head syndrome in broiler chickens in Japan: Its pathology, microbiology and biochemistry. Avian Pathology 26 139-154.

Prasad V, Murthy KK, Rao TV J 1997: In vitro antibiogram studies of E. coli in chickens. Indian Veterinary Journal 76 616-617.

Rocio C, Shivaprasad HL, Droual R, Richard P, Chin P, Woolcock R, Carpenter TE 1998: Inclusion body tracheitis associated avian adenovirus in turkey. Avian Diseases $\mathbf{4 2}$ 589-596. 
Saif YM, Barnes HJ, Glisson JR, Fadly AM, McDougald LR, Swayne DE 2003: Diseases of Poultry. 11 $1^{\text {th }}$ edn. Iowa State University Press. Blackwell Publishing Company, London, United Kingdom pp. 849.

Sharada R, Krishnappa G, Raghavan R, Sreevinas G, Upandra HA 1999: Islation and serotyping of $E$. coli from different pathological conditions in poultry. Indian Journal of Poultry Science 34 366-369.

Sukhon ESN, Musa A, Attar MAl 2002: Studies on the bacterial etiology of airsacculitis of broilers in Northern and Middle Jordan with special reference to Escherichia coli, Ornithobacterium rhinotracheale and Bordetella avium. Avian Diseases 46 605-612.

Trkyilmaz S 2005: Isolation and serotyping of Ornithobacterium rhinotracheale from poultry. Turkish Journal of Veterinary and Animal Science 29 1299-1304.

Vandamme P, Segers P, Canneyt VM, Houe VK, Mutters R, Hommez J, Dewhirst F, Paster B, Kersters K, Falsen E, Devriese ELA, Brisguard M, Hinz KH, Mannheim W 1994: Ornithobacterium rhinotracheale gen. nov. sp. nov, isolated from the avian respiratory tract. International Journal of Systematic Bacteriology 44 24-37.

Yousseff FM, Mona AA, Mansour DH 2008: Epidemiological studies on bacteriological aspects of air sacculitis in chickens. Association of Veterinary Medicine Journal 54118.

Zorman ROI, Zdovc D, Bencina IM 2000: Infection of turkeys with Ornithobacterium rhinotracheale and Mycoplasma synoviae. Avian Diseases 44 1017-1022. 